\title{
O 'mau desempenho' de Lugo: gênero, religião e contramovimento na última destituição presidencial paraguaia
}

\author{
José Szwako \\ Programa de Pós-Graduação em Ciência Política \\ Universidade Federal do Paraná \\ Núcleo Democracia e Ação Coletiva (CEBRAP)
}

\begin{abstract}
Resumo: $O$ artigo analisa o enredo de gênero subjacente ao julgamento político que, por meio da acusação de 'mau desempenho', tirou Fernando Lugo da Presidência do Paraguai. Para tanto, se utiliza originalmente da noção de contramovimento e se inspira nas críticas feministas à dicotomia público-privado. Após apresentar as reações imediatas à destituição de Lugo, o artigo aborda os 'escandalosos' casos de paternidade presidencial, bem como a atuação de organizações 'pró-vida' agrupadas ao redor de 'Queremos papá y mamá'. Sublinha-se, nos casos analisados, a articulação entre padrões de gênero e valores religiosos, moldada pela matriz bélico-nacionalista de seus defensores. Argumenta que, com efeito, um 'mau desempenho' moral contornou e completou o julgamento do ex-presidente paraguaio. É sugerida, ao fim, a entrada tanto do par movimento/contramovimento quanto dos atores religiosos, e de seus impactos institucionais, na agenda das análises de movimentos sociais.
\end{abstract}

Palavras-chave: contramovimento; gênero; impeachment; Fernando Lugo; ação coletiva

Abstract: This article examines the gender subtext underlying the political judgment that recently took Fernando Lugo of Paraguay's presidency. It departs from the original notion of countermovement and it is inspired by feminist critics of public. private dichotomy. After presenting the immediate reactions to the dismissal of Lugo, the article discusses the political usages of presidential paternity cases, and the performance of 'pro-life' groups of 'Queremos papá y mamá' countermovement. The analysis of these cases shows the relationship between patterns of gender and religious values. In a moral vein, this relationship shapes Lugo's 'poor performance' and completed the trial of former Paraguayan president. At the end, it is suggested the entry of both, the movement/ countermovement dynamics and the religious conservative actors in the social movements analysis.

Keywords: countermovement; religion; gender; impeachment; Fernando Lugo; collective action 
SZWAKO, J. O 'mau desempenho' de Lugo: gênero, religião e contramovimento...

"O Paraguai tem que ser construído entre todos os setores: colorados e liberais, cerristas e olimpistas, católico e não-católico, com a união de todos os partidos políticos e os movimentos sociais."

"Nós podemos perder as eleições, mas a família e Deus jamais perderemos."

Federico Franco

Momentos de refundação e tensão do contrato social exigem falas eloquentes e altissonantes. Foi logo após receber o bastão do mandato paraguaio, em 22 de junho de 2012, que Federico Franco mui atento ao protocolo pedia o apoio e a 'união de todos os setores' do país. Quase dois anos antes, ao falar em defesa da família e de Deus, o então vice-presidente foi ovacionado por apenas um daqueles setores. No protesto de 2010, diante do político liberal e ao lado de figuras da hierarquia eclesiástica paraguaia, estavam cerca de três mil fiéis mobilizados pelo movimento 'Queremos papá y mamá'. As autodenominadas organizações 'pró-vida', líderes deste movimento, contaram com o apoio franquista para expressar em público sua preocupação (um tanto exagerada, veremos) com relação à lei do matrimônio entre pessoas do mesmo sexo, conquistada pouco tempo antes na vizinha Argentina.

O episódio que está entre os eventos de 2010 e 2012, e que também tirou Federico Franco da vice-Presidência do país, é o julgamento político de Fernando Lugo. Este artigo parte da atuação dos personagens e dos roteiros em disputa nessas duas e em outras cenas de mobilização para iluminar o enredo de gênero que permeia e estrutura a última substituição no topo do Executivo paraguaio. Tal enredo pode ser observado com base nas batalhas travadas entre concepções generificadas de mundo, concepções de família, 'normalidade', 'valores', dentre tantas outras. Mais que isso, porém, vamos argumentar que uma forma complexa e nacionalista de mediação entre padrões de gênero e moral religiosa serviu como a principal fonte não institucional de legitimação da queda de Lugo. Pois, enquanto o argumento do 'mau desempenho' foi a razão institucional levantada em julgamento - apenas parcialmente aceita pela cidadania paraguaia - para destituir aquele presidente, uma variação generificada e moralizada desse mesmo 'mau desempenho' operou no sentido de justificar e selar a despedida luguista.

Para chegar a estas conclusões, duas matrizes teóricas informam nossa abordagem. Por um lado, parte-se do diálogo travado pelas teóricas feministas com a Ciência Política e, especificamente, com a teoria política contemporânea (inter alia Okin, 1989; Young, 1990). No debate brasileiro, esse diálogo é recente e suas reflexões envolvem a crítica de categorias adequadas para notar e ultrapassar as desigualdades vividas pelas mulheres em âmbito político-público (BIROLI E MIGUEL, 2012; SzWAKO e Adelman, 2010). Para os fins da análise do caso de Lugo, parte-se de um insight feminista fundamental: os mundos privado e público apenas ideológica e forçosamente correspondem a feminino e masculino, e, mais ainda, eles não estão desligados nem são opostos (PATEMAN, 1993); ao contrário, privado e público se formam e se informam por uma miríade de conexões e modos de difícil apreensão, mas cujo exemplo da análise da destituição presidencial paraguaia pode, com efeito, deslindar.

Nossa segunda chave de inspiração teórica é uma Sociologia das formas de mobilização e protesto de atores não institucionais em relação com autoridades institucionais (GOLDSTONE, 2003; TILLY e TARROW, 2007; TARROW, 2009). Distinguida por sua ênfase nas interações com a polity e pelo uso de 
categorias voltadas para a análise da chamada 'política do confronto' ou 'contestatória', essa embocadura vem sendo, recentemente, incorporada ao debate brasileiro a respeito dos movimentos sociais ${ }^{1}$. Tal incorporação parece render heuristicamente e tende a assumir vários sentidos. Enquanto parte da bibliografia especializada já considerava centralmente as trajetórias e articulações travadas entre sociedade civil e Estado (Cf. Dagnino et al, 2006), outra parte vem se beneficiando do diálogo com essa matriz anglossaxã para explorar âmbitos e modalidades de interação sócio-estatal além e aquém da contestação, sem necessariamente suprimi-la, como estratégia civil de influência (p.e., Abers et al, 2011).

Para os fins deste artigo, vamos nos ater à raiz interacionista dessa matriz anglossaxã, destacando um conjunto de formas, não necessariamente violentas, de aproximação e de interação entre atores sociais e autoridades paraguaias. No entanto, à diferença da tendência no debate brasileiro, recorremos a uma noção negligenciada por este debate, qual seja, a noção de contramovimento. De modo genérico, um contramovimento pode ser entendido "como redes de pessoas e organizações que compartilham muitos objetos de preocupação com o movimento social ao qual elas se opõem" (MEYER E STAGGENBORG, 1996, p.1632). Caso adequado de contramobilização é o protesto no qual foi ovacionada a defesa franquista da 'família' e de 'Deus', organizado por 'Queremos papá y mamá'. Neste caso, as organizações 'pró-vida' à frente daquele evento parecem compartilhar com parte do movimento LGBTI paraguaio um objeto de preocupação: o matrimônio e sua ampliação jurídica somente para pessoas de sexos distintos, ou para além delas. Do ponto de vista teórico, a incorporação do contramovimento mantém aquela ênfase interacionista ao mesmo tempo em que a desloca, levando a uma análise triangular da ação coletiva - tal com sugere a Figura 1. A partir desse deslocamento, junto às interações sócio-estatais, emerge um nível de análise propriamente sócio-civil, no qual importam disputas, reciprocidades e propriedades operantes entre grupos advindos da sociedade civil alinhados, de parte a parte, com autoridades ou realidades institucionais.

Figura 1

Esquema sintético das análises (tradicional e triangular) das relações Estado/atores civis

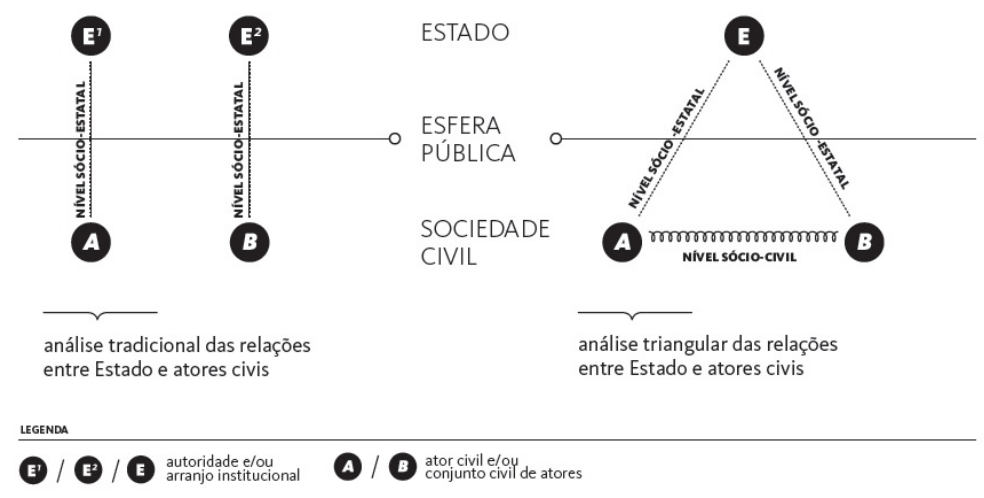

\footnotetext{
1 Veja-se, por exemplo, os dossiês 'Dinâmicas da Ação Coletiva' (2011) e 'Movimentos sociais e ação coletiva' (2010) publicados, respectivamente, em Sociologias e na Revista Brasileira de Ciência Política.
} 
SZWAKO, J. O 'mau desempenho' de Lugo: gênero, religião e contramovimento...

Antes de passar aos episódios nos quais é possível ver a reação católica civilmente organizada em defesa de um ideal de 'família paraguaia', vamos observar o contexto no qual se deu a destituição de Fernando Lugo e seus efeitos imediatos sobre frações da sociedade civil, bem como sobre a opinião pública paraguaia. Tendo a figura acima em mente, a observação das reações civis à mudança institucional será útil adiante por duas razões complementares: elas dão acesso às matrizes discursivas que informam a performance de atores tanto civis quanto políticos; e, além disso, elas permitem ver o alcance explicativo contido em uma análise centrada no par movimento/contramovimento, isto é, no jogo das oposições sócio-civis alavancado, neste caso, pelo impeachment de Lugo.

\section{Reações à queda de Lugo: 'Paraguay resiste' e 'Paraguay es soberano'}

Controversa, a queda de Lugo tem raízes e razões múltiplas e que tendem a se reforçar mutuamente. Dentre outras raízes estão: o isolamento do Executivo e seu baixíssimo nível de apoio parlamentar, expressos nas votações derradeiras em ambas as Casas parlamentares; um desenho eleitoral fechado com efeitos oligárquicos, contra o qual partes da sociedade civil vinham se posicionando, mas defendido pela Câmara de Deputados; o fomento discreto por parte do governo Lugo de ações que supostamente colocariam em risco o interesse da parte predominante no embate entre corporações de capital internacional e atores locais campesinos, em disputa por terra e pelo seu uso adequado no que tange à segurança alimentar e ambiental; e, uma política de alcance limitado relativamente ao combate de grupos paramilitares, em relação aos quais a figura presidencial foi midiática e repetidamente associada.

Se estes fatores já davam os contornos e tensões da política paraguaia, a gota d'água para deflagrar a crise institucional foi o chamado 'caso de Curuguaty'. Neste episódio, o confronto entre policiais e 'carperos', nome dado a uma fração dos sem-terra paraguaios, teve como resultado a morte de 17 envolvidos e serviu de estopim para o impeachment. O caso de Curuguaty encarna o presente e o passado das disputas por terra e sua desigual e ilegal distribuição no país, pois o próprio terreno onde se deu a trágica contenda pertence ao grupo empresarial de um ex-senador, cuja aquisição se deu nos moldes herdados do autoritarismo stronista ${ }^{2}$. Seja desde a institucionalidade ou de fora do Paraguai, não faltam versões e farpas para acusar quem é o responsável pelo massacre: enquanto alguns falam de 'narcocoloradismo', de 'encenação' e 'armação' contra o Lugo, outros acusam o ex-presidente de defender os sem-terra e de não 'reagir à altura' do episódio.

Disparado o estopim, e após uma estratégica aliança entre liberais e colorados, a ideia de 'falta de segurança' deu o tom das acusações formalizadas no julgamento político desenrolado e concluído exatamente uma semana após o ocorrido em Curuguaty. Entre as cinco acusações dirigidas ao expresidente estavam: i) a politização das Forças Armadas, em um evento de 2009 no qual a 'Iuta de classes' teria sido 'instigada' (p.2); ii) a aprovação por parte de Lugo do Protocolo de Ushuaia II que, por prever sanções aos e dos países do MERCOSUL em casos de ruptura democrática, constituiria ipsis litteris 'um ATENTADO CONTRA A SOBERANIA da República do Paraguai' (p.5); iii) a 'crescente insegurança' vivida devido, dentre outros fatores, ao grupo paramilitar Ejército del Pueblo Paraguayo, bem como à 'conduta complacente do Presidente' (p.3); iv) o 'caso Ñacunday', menos violento, porém

\footnotetext{
2 Veja-se, especificamente sobre a propriedade em questão, 'Adjudicaciones a personas no beneficiarias' (COMISIÓN DE VERDAD Y STICIA, 2008, p.31).
} 


\section{OPINIÃO PÚBLICA, Campinas, vol. 20, no 1, abril, 2014, p. 132-155}

análogo ao v) 'caso de Curuguaty' que "demonstrou (...) a patente inoperância, negligência, inaptidão e improvisação deste governo liderado pelo Presidente Fernando Lugo, que merece a acusação da Câmara de Deputados por mau desempenho de suas funções frente à Câmara de Senadores" (PARAGUAY, 2012, p.6) (Grifo no original).

Se a ideia de 'insegurança' permeou parte das acusações dirigidas ao ex-presidente, a expressão 'mau desempenho' operou como forte sintetizador de todas elas. 'O mau desempenho de Lugo cansou os paraguaios' - este é o título do editorial de um dos maiores jornais de Assunção dois dias após a destituição presidencial (ABC COLOR, 2012). Merecida ou não, essa acusação foi feita pelos parlamentares paraguaios sem fundamentação substantiva, pois "todas as [cinco] causas mencionadas são de público conhecimento, motivo pelo qual não precisam ser provadas, conforme ordenamento jurídico vigente" (PARAGUAY, 2012, p.8) ${ }^{3}$. Sem provas contra as quais pudesse se opor e sequer prazo minimamente razoável, a defesa não impediu a destituição presidencial transcorrida sem recurso a forças e meios extrainstitucionais, isto é, transcorrida mais ou menos dentro das regras democráticas e através delas, sobretudo.

O impeachment presidencial cindiu a opinião pública paraguaia. Um dia antes da queda de Lugo, pesquisa realizada por organizações civis mostrava $67 \%$ da cidadania contra o julgamento político' 4 . Passado quase um mês, o revezamento não-eleitoral contava com $56 \%$ de aprovação e $41 \%$ de reprovação, de acordo com outra pesquisa de opinião ${ }^{5}$. Ao contrário da conclusão jornalística daí derivada, segundo a qual 'a maioria confere legitimidade à recente mudança política' ${ }^{6}$, esses dados permitem inferir, no máximo, que o julgamento político e sua decisão final polarizaram a opinião no país. Como veremos, uma parte da sociedade paraguaia reagiu à destituição no sentido de se opor a ela, rotulando-a de 'golpe', enquanto outra parte endossa aquilo que vê apenas como um processo regular cujo desenlace foi a queda de Lugo.

De modo interessante, a aparência legal emprestada ao processo tende a operar como uma robusta fonte de legitimação para estes últimos, 'cansados do desempenho' luguista. No conjunto das tomadas públicas de posição que elogiam a posse do governo franquista e o resultado do impeachment, o recurso à dimensão legal-institucional do processo é central. "No Paraguai não houve nenhuma ruptura da ordem constitucional" (ABC COLOR, 2012) - difundida para muito além das fronteiras paraguaias ${ }^{7}$, essa assertiva diz, em negativo, que 'tudo ocorreu dentro das regras'. Mais que isso, segundo essa perspectiva, o cenário pós-impeachment seria de 'calma':

\footnotetext{
${ }^{3}$ Não é nosso propósito aqui entrar nos meandros e embates jurídicos a respeito da necessidade e da falta das provas contra o ex-presidente. Basta notar que a tentativa de defesa apresentada pelos advogados de Fernando Lugo contesta expressamente a ideia de que o 'ordenamento jurídico' permitiria prescindir do recurso a tais provas.

${ }^{4}$ Cf. Méndez Pereira, 2012.

${ }^{5}$ Cf. Aquino, 2012

$6 / d e m$.

7 Veja-se, por exemplo, isto: "Lugo foi afastado do governo, nos estritos termos da Constituição, por mau desempenho. É de se lembrar que o Parlamento tem representantes da totalidade da nação (situação e oposição). O Executivo, só da maioria (situação). Tanto foi tranquilo o processo de afastamento no Paraguai que não existiram manifestações de expressão em defesa do ex-presidente. As Forças Armadas nem precisaram enviar contingentes à rua, e Lugo continuou com toda a liberdade para expressar as suas opiniões e até para montar um governo na sombra. Processo digno das grandes democracias parlamentares" (MARTINS, 2012) (Grifos meus)
} 
SZWAKO, J. O 'mau desempenho' de Lugo: gênero, religião e contramovimento...

"[e]m virtude do artigo 225 da Constituição Nacional, o presidente foi submetido a julgamento político. Ele se submeteu ao mesmo, segundo declarou desde o início, 'com todas as suas consequências'. Nessa mesma tessitura, acatou seu resultado.

As Forças Armadas respeitaram o processo civil e, como corresponde, aceitaram a sentença das instituições administradas por suas autoridades legítimas. O país está em calma e o novo presidente da República conta com o apoio amplo e majoritário dos partidos políticos. Onde, então, está a quebra, a ruptura ou a ameaça à democracia?" (ABC COLOR, 2012).

À diferença do que sugerem essa e outras opiniões, no entanto, o Paraguai pós-impeachment não ficou 'em calma', como se a população paraguaia em sua maioria ou totalidade tivesse aceitado sem mais tal processo. A destituição de Lugo gerou duas reações, duas correntes ou grupos abrangentes que seguem o tom daquela polarização na opinião e se diferenciam a partir das autodenominações 'Paraguay resiste' e 'Paraguay es soberano', contra a destituição presidencial e a favor dela, respectivamente.

Partes significativas de atores seja da sociedade civil ou do sistema político paraguaio vêm 'resistindo' ao governo de Federico Franco, de modo a questionar sua legitimidade. Para estes atores, a queda de Fernando Lugo tem apenas um nome com vários predicados: 'golpe', 'golpe parlamentar', 'golpe constitucional', 'golpe branco'... Ainda que tenham sítio próprio na internet ${ }^{8}$, as vozes da 'resistência cidadã', como também se intitulam, não conformam uma articuladora formalizada; estão, antes, agrupadas para trazer a público sua perspectiva sobre a destituição presidencial. "Denunciamos que no Paraguai estamos atravessando um dos momentos mais duros da construção democrática", diz em nota a Coordenação Nacional de Mulheres Trabalhadoras Rurais e Indígenas (CONAMURI), rede componente dessa opinião e que segue: "devido ao Golpe de Estado Parlamentar realizado de forma altamente irregular e carente de argumentos, no qual foram violados todos os prazos processuais e as garantias constitucionais básicas de defesa do presidente Fernando Lugo" 9 .

Embora a composição interna da 'resistência' seja bastante múltipla, do mesmo modo que é heterogênea a proximidade ou distância de seus atores em relação ao governo de Lugo, é possível fazer um perfil que os atravessa e alinha: se trata fundamentalmente de pessoas, redes e organizações mobilizadas muito antes do processo por elas chamado de 'golpe'. Um dia após o impeachment, parte desses atores - associações e partidos de esquerda e centro-esquerda agrupados na chamada 'Frente Guasú', base não parlamentar de apoio a Lugo - conformou a chamada 'Frente Nacional por la Defensa de la Democracia'. Esta última 'frente' é não apenas a face mais partidarizada de 'Paraguay resiste' como, devido a seu alcance nacional, aquela que conta com mais recursos organizacionais e humanos para fomentar protestos de rua 'antigolpe', sustentados intermitentemente e transcorridos por departamentos e cidades de todo o país.

Episódio marcante e aglutinador na formação desta reação foi a tentativa de fechamento da televisão pública por parte do governo recém-empossado. Localizado no centro da capital paraguaia, o edifício do canal teve suas frente e adjacências ocupadas por militantes de diversos movimentos em oposição às forças governistas, de modo a atrair grupos de jovens, ligados ou não a organizações, e a se

${ }^{8}$ Veja-se: <http://paraguayresiste.com>.

${ }^{9}$ Cf. Conamuri (2012). 


\section{OPINIÃO PÚBLICA, Campinas, vol. 20, no 1, abril, 2014, p. 132-155}

tornar inicialmente o 'foco da resistência' (ESTIGARRIBIA, 2012, p.19). A modalidade básica de ação das pessoas ali reunidas foi o chamado 'micrófono abierto', nome copiado de um programa de debate da televisão estatal. Através do 'micrófono', os grupos e indivíduos reforçavam laços com suas palavras de ordem, posicionando-se pública e 'pacificamente' em oposição ao 'golpe'. Entre os momentos de fala, formas artístico-culturais de expressão, tais como teatro, música, intervenção poética, dentre outras, tiveram vez no conjunto dessa mobilização que durou ao redor de uma semana. De modo interessante, estes modos alternativos de expressão 'antigolpe' se alastraram posteriormente ao episódio institucional sob a forma de festivais de música e cinema, peças de teatro, rodas de debate e tertúlias na grande Assunção.

Se 'resistência' é o termo que engloba e dá uma identidade plástica aos grupos contrários à substituição presidencial, 'pacífico' é o tom de sua reação. Os protestos contra o governo de Federico Franco tiveram majoritariamente caráter notadamente não violento, evidenciado pela ausência de embates abertos e mortais entre policiais e manifestantes. Isso não significa que tais interações, em nível micro, estejam desprovidas de altas doses e episódios de tensão, rapidamente remediados pelos próprios manifestantes que se recordam da natureza pacífica de seus meios de protesto ${ }^{10}$. Junto da feição artístico-cultural das práticas da 'resistência cidadã', sua natureza não conflituosa talvez seja a razão pela qual vários analistas, paraguaios ou não, acreditam que o Paraguai pós-impeachment é uma calmaria só - e que, portanto, não haveria questionamentos sobre a destituição presidencial. O próprio Fernando Lugo, ao acatar a decisão do Congresso, pediu a seus apoiadores que fizessem 'protestos pacíficos'. Ainda que tal demanda tenha algum peso na orientação das manifestações, fator relevante na disposição não violenta dos militantes 'antigolpe' pode estar na relativamente recente e dolorosa memória que boa parte desses mesmos militantes guarda do ciclo de protestos do 'Março paraguaio'11, cujo saldo foi um presidente deposto e oito manifestantes mortos. Além disso, observando-se a parte estatal das interações entre 'resistência' e forças repressivas, é possível notar que o registro interativo de 'pacificidade' interessa também a estas últimas, pois, para o governo de fato, seria demasiado alto o preço pago por uma eventual fatalidade, que poderia colocar em jogo sua já questionada legitimidade ou, mesmo, colocar em risco o contrato social paraguaio, tal como ocorreu no ciclo do 'Março' de 1999.

Em sentido oposto ao da 'resistência', o grupo 'Paraguay es soberano' defende a legitimidade do governo de Federico Franco. Sua conformação primeira se deu com a abertura de espaços na internet ${ }^{12}$, nos quais se mobilizou um grupo inicialmente restrito de cidadãos 'indignados com as notícias transmitidas em nível internacional', segundo a fala de sua principal porta-voz. O adjetivo 'soberano' aí significa um rechaço das primeiras respostas internacionais, em especial aquelas de Argentina e Venezuela, de não-reconhecimento da posse de Franco. Direcionado contra 'estranhos', o apoio ao governo franquista utiliza como seu lema o primeiro artigo da carta de independência do país: "La República del Paraguay en el Río de la Plata es para siempre de hecho y de derecho una nación libre e independiente de todo poder extraño".

\footnotetext{
10 Veja-se, por exemplo, os chamados 'escraches' que consistem em materiais nos quais partidos ou figuras políticas ligadas ao novo governo são ridicularizados; ver em: <http://www.sinmiedoapensar.net/news/escraches-no-violentos/>.

11 Cf. Szwako (2012a).

12 Veja-se: <http://paraguaysoberano.org/> e, para o depoimento que descreve a gênese e marca a ampliação do alcance desta corrente: <http://www.youtube.com/watch?v=9M3C3h144FM>.
} 
SZWAKO, J. O 'mau desempenho' de Lugo: gênero, religião e contramovimento...

Do ponto de vista de sua composição interna, o perfil desta corrente parece eminentemente urbano e, embora conte com importantes figuras da direita partidária entre seus fundadores, reivindica para si um desligamento em relação aos partidos. “'Paraguai es soberano' é uma página sem bandeira política, sem fins lucrativos; criado única e exclusivamente para demonstrar que o Paraguai é livre, independente e que [nós] cidadãos estamos dispostos a lutar por nossa soberania". Em sua definição daquilo que esperam do país, são destacados termos como 'governabilidade', 'emprego', 'mobilidade social', 'equidade social', 'honestidade', 'Estado estratégico, promotor e eficiente'.

Afins àquela acusação de que a cláusula democrática do MERCOSUL representa um atentado à soberania paraguaia, estes cidadãos são, em grande medida, os que estavam 'cansados' do desempenho luguista. Vários traços das acusações levantadas em julgamento contra Lugo permeiam as páginas de 'Paraguai es soberano', bem como os comentários de seus seguidores. Esses mesmos traços ficaram sintetizados no inflamado depoimento dado pela principal porta-voz dessa corrente que, em uma semana, atraiu quase 50.000 apoiadores. A citação é longa, mas vale a pena:

"[Eu] estava muito indignada com o que estava acontecendo e com as notícias transmitidas em nível internacional. Foi grande a minha surpresa quando vi que, em três horas, éramos mais de cinco mil pessoas entrando nesses sites.

(...) [A]s vozes de silêncio, [as vozes] das redes sociais, estão gritando, estão aclamando, estão muito ofendidos, e querendo demonstrar ao mundo o que realmente aconteceu no Paraguai. Que não venham querer nos dizer o contrário.

(...) Minha presença [na Plaza de Armas] (...) é para te mandar uma mensagem, Fernando Lugo. Tenho isso atravessado na garganta desde 2008. (...) Teu problema foi... Quando você jurou perante a Bíblia, assumiu a condução deste país e prometeu ser um bom governante para este povo, você não cumpriu a sua promessa. Hoje eu venho te processar - Deus, a pátria e o povo vão te processar. Eu venho te processar, pois você se matou de dar risada, do teu povo, da tua igreja, do teu Deus, do teu país! Quem você achou que é, Fernando Lugo? Que merda você foi, para nos fazer isso? Para nos fazer passar o ridículo, não podíamos mais pisar em outro país, porque nos diziam: 'ah, esse país que tem como governante um ex-bispo que engravidou meio país'.

(...) Deixe de nos fazer passar este martírio. Saia do poder, se alije. Vai com as tuas mulheres, vai para o campo, para onde quer que seja.

(...) Deixe-nos em paz. Queremos, por favor, trabalhar; queremos viver e produzir com tranquilidade. Queremos que o último campesino, o último policial possa sair e ir ao interior do país com segurança. Você [Lugo] nos tirou tudo, nos tirou a dignidade.

(...) Hoje aqui na praça não tem ninguém por sua culpa, [nós] os paraguaios temos medo. Por tua culpa, foram assassinados e massacrados esses paraguaios.

(...) Não te reconhecemos mais como Presidente da República. Nós te demos a condução da [seleção de futebol] albirroja. Você foi nosso capitão e nos traiu.

(...) No primeiro ano de governo, te demos cartão amarelo (...). O povo tinha uma esperança em um bispo com todos os discursos e preceitos, e você foi o diabo para este 


\section{OPINIÃO PÚBLICA, Campinas, vol. 20, no 1, abril, 2014, p. 132-155}

país. É mais, Fernando Lugo, e que o mundo inteiro saiba, aqui não houve ruptura, aqui te demos cartão vermelho, te expulsamos do jogo".

Com eloquência e apelo inegáveis, apenas interrompida por calorosos aplausos e gritos 'fuera Lugo', esta mensagem ao ex-presidente veicula os elementos e argumentos que estiveram na base da destituição presidencial. Enquanto a ideia de 'insegurança' e o episódio de Curuguaty se expressam no ‘medo' e em uma compaixão com policiais e campesinos, o 'mau desempenho' de Lugo estrutura toda a fala: a despeito de sua 'promessa', ele não foi 'um bom governante'; para esse público 'indignado', Lugo falhou, ele foi o 'diabo', tendo merecido e levado 'cartão vermelho'. E, ao contrário do que pode parecer, essa 'expulsão' se deu 'sem ruptura', quer dizer, dentro das regras ou quase. Disso dá prova outro intelectual nutrido em linguagem autorizada, compartilhado pelos apoiadores ativos do governo franquista: "uma das primeiras tarefas imperativas do novo Governo [sic] é fazer com que a sociedade internacional note que o processo político que vive o Paraguai não é resultado de um Golpe de Estado Institucional"13.

Em que pesem as metáforas futebolísticas, bem como os pressupostos e valores de classe que permeiam a fala da fundadora de 'Paraguay es soberano', é sobre as representações e convenções tanto de gênero quanto religiosas de seu depoimento que nos debruçaremos mais adiante. Por ora, concluindo este tópico, vamos notar o jogo de acusações e apropriações entre ambas as reações que dá forma a uma dinâmica típica de movimento/contramovimento.

Sobre aqueles que 'resistem' à nova administração governamental tem recaído a pecha de 'Iuguistas'. Contra essa acusação, parte deles afirma que é mais amplo o quid da questão, pois eles estão, não 'em defesa de Lugo', mas do processo democrático paraguaio - o mesmo que, segundo os 'soberanistas', não teria sido maculado. A estes últimos, por meio de uma foto na qual se vê um avião fumigando uma plantação, é dirigida a pergunta: 'Isto é soberania?'. Outros materiais de 'escraches' não violentos dizem que 'não há soberania sem democracia' e 'não há paz sem justiça'. Embora acuse seus adversários de 'golpistas' e 'fascistas', rótulos nos quais entram tanto figuras políticas quanto seus apoiadores, a fração 'resistente' dirige suas formas de difamação centralmente contra o novo presidente: 'Frauderico', 'Florerico' e 'presidentrucho' são algumas provocações a Franco.

Já a reação dos indivíduos ligados a 'Paraguay es soberano' encontra sua principal fonte de inspiração nos atores internacionais e em suas ações. Exemplo disso foi a postura adotada pelos países vizinhos, interpretada em registro nacionalista pela fração 'soberanista' da opinião paraguaia. Em tal registro, ao sancionar parcialmente o país via MERCOSUL, externamente uma 'tríplice aliança' violentaria o Paraguai e o direito do 'povo a utilizar democraticamente sua Constituição'14, enquanto internamente aqueles opostos ao novo governo encarnariam os 'legionários do século XXI'15, porque supostamente 'traem a pátria' tal como no grande conflito do XIX.

O tom dessa reação foi acirrado ainda mais com a entrada parcial da Venezuela no bloco regional. Frente às tomadas internacionais de decisão, um acervo de práticas e expressões herdadas do autoritarismo stronista voltou não somente ao debate público, mas também às ações governamentais.

\footnotetext{
13 Veja-se: <http://www.noticiasclic.com/lugo-conto-con-el-debido-proceso-segun-jurista>.

14 Veja-se: <http://www.lanacion.com.py/articulo/77774-volvio-la-triple-alianza.html>

${ }^{15}$ Veja-se: <http://www.abc.com.py/edicion-impresa/editorial/los-legionarios-del-siglo-xxi-426353>.
} 
SZWAKO, J. O 'mau desempenho' de Lugo: gênero, religião e contramovimento...

Os grupos e indivíduos 'antigolpe' são minados por categorias anticomunistas, sendo chamados de 'párias', 'esquerdistas', 'socialistas do século XX' e 'marxistas bolivarianos'. Ao passo que uma inquisição nacionalista é encetada por iniciativas institucionais como tirar de ruas e praças o busto de Simon Bolívar, perseguir os parcos congressistas pró-Lugo e convocar desfiles à la Stroessner por um 'Paraguai livre, independente e soberano'16.

Dada a polarização pela qual passou a opinião pública pós-impeachment, esses ataques e contra-ataques não surpreendem, mas permitem notar 0 traço básico do par mobilização/contramobilização, qual seja, o compartilhamento de um, ou mais de um, 'objeto de preocupação' - a destituição de Fernando Lugo. Mas este objeto de tematização não é a única coisa partilhada entre 'soberanistas' e 'resistentes'. Subjacente à troca de acusações e (supostas) difamações, opera também uma apropriação das táticas de expressão empregadas pelas partes. Exemplo dessa apropriação girou ao redor do chamado 'micrófono abierto'. Embora tenha marcado a aglutinação inicial da 'resistencia ciudadana', o 'micrófono' foi rapidamente incorporado pelos apoiadores do novo governo, tendo servido de suporte técnico para a vocalização daquela mensagem 'indignada' dirigida ao ex. presidente. Essa mesma lógica de apropriação se dá com relação ao tom dos protestos, pois mesmo a fração da opinião que não teve, como não tem, de encarar a potência destrutiva das tensões frente a forças repressivas, passou a convocar mobilizações 'pacíficas'. Por fim, lógica análoga ocorre com aqueles modos artístico-culturais de mobilização que, inicialmente de um lado da disputa, são ressignificados por eventos como o 'Festival' e a 'Jornada familiar pela paz e pela soberania'. Via apropriação, quer dizer, não necessariamente de forma original, 'soberanistas' e 'resistentes' dividem também modalidades de expressão pública através das quais tentam convencer, com sinais opostos, partes do público cívico paraguaio e da opinião internacional a respeito do 'que realmente aconteceu no Paraguai'.

Esses dados acerca das respostas à queda de Fernando Lugo dão uma pista da fecundidade analítica do par movimento/contramovimento. Ao e por se deslocar de um eixo de análise estritamente sócio-estatal, é possível visualizar uma dimensão pública na qual se desenrolam tomadas de posição e oposição entre atores civis. Dentre elas, a performance de 'Paraguay es soberano' interessa especialmente, pois afinal é essa a corrente que dá suporte ativo ao novo governo. Ainda que a legalidade ritual do episódio, escorado em um 'mau desempenho', tenha servido como fonte de legitimação para os 'soberanistas', essa aparência legal não age de maneira isolada. Padrões e valores de gênero também operaram aí e em duplo sentido, para deslegitimar a figura de Fernando Lugo e para legitimar sua queda. Aquela inflamada mensagem ao ex-presidente veicula tais padrões - que 'martírio', que papel 'ridículo', um presidente e ex-bispo que 'engravidou meio país'; 'deixe o poder', clamava, 'vá com suas mulheres'. No próximo tópico, vamos observar as representações e estratégias travadas ao redor da vida íntima de Lugo e como elas anteciparam e deram os contornos propriamente morais de seu 'mau desempenho'.

${ }^{16}$ Veja-se: <www.ultimahora.com/notas/545694-MEC-anuncia-desfile-estudiantil-Paraguay-libre,-independiente-y-soberano>. 


\section{OPINIÃO PÚBLICA, Campinas, vol. 20, no 1, abril, 2014, p. 132-155}

\section{Os dilemas e 'escândalos' ao redor das paternidades de Lugo}

"É certo que houve uma relação com Viviana Carrillo, frente a isso assumo todas as responsabilidades que puderam derivar de tal fato reconhecendo a paternidade do menino" - foi com estas palavras que, em plena Semana Santa de 2009, o ex-presidente Lugo assumiu seu primeiro caso de paternidade. Antes concentrada em organizações civis de luta por direitos da família, da criança e do adolescente, a questão da responsabilidade paterna se espalhou desde então pelo debate público paraguaio (BAREIRO, 2009). Em defesa própria, Lugo se disse 'uma pessoa humana imperfeita, fruto de processos históricos e culturais'. Poucos dias após aquela declaração, mais 'imperfeições' dele vinham a público com outras duas acusações de paternidade não reconhecida. Essas denúncias tocavam um universo de relações demasiado sensível para qualquer país profundamente católico como o Paraguai, pois elas diziam respeito a uma época na qual Lugo ainda era representante da hierarquia eclesiástica.

Dadas as mínimas condições para um festival midiático em torno da intimidade do então exbispo presidente, as reações às denúncias permitem ver que o impeachment presidencial era já um objeto plausível no horizonte. 'Ao se fazerem públicos os assuntos de sua vida privada, colocou-se em risco a credibilidade do cargo que exerce o presidente Lugo'17 - o 'escândalo paraguaio' foi tema de editoriais no Paraguai e fora dele. No espectro partidário-ideológico do país, um profundo mal-estar calou as esquerdas, enquanto as direitas agiram. Os movimentos e partidos que apoiavam o ex. presidente percebiam que, "se Lugo é criticado, faz-se o jogo da direita e é afiançada a queda de Lugo, que dará vez a um governo muito mais antipopular" (ORTIz, 2009, s/p). Posturas 'indignadas' midiáticas ou eclesiásticas sobraram, mas elas foram mal compreendidas por boa parte da população paraguaia que ou era elogiosa com um presidente toro ou não via nada de muito excepcional na paternidade irresponsável. "Mas por que eles discutem tanto", exclama uma entrevistada de Ortiz, pois, diz ela, "faz tempo que isso acontece no interior, faz tempo que os sacerdotes têm muitos filhos" (apud ORTIZ, 2009). Com uma só tacada, a dupla moral operante no bojo da hierarquia católica é, nesta fala, desvelada e seu caráter patriarcal aceito.

As paternidades de Lugo geraram vários e duros ataques. 'Nunca um governo denegriu tanto a dignidade da mulher como o do atual padre presidente do Paraguai' - disse um formador de opinião anti. Lugo $^{18}$. Assentado na ideia de 'dignidade', esse argumento reproduz alguns eixos de discursos nacionalistas que, mundo afora, reservam às mulheres a reprodução biológica da nação e a participação delas nas batalhas nacionais (YUVAL-DAVIS E ANTHIAS, 1989) ${ }^{19}$. 'Abastecendo trincheiras' e 'curando combatentes' - mais que um elogio às mulheres, este é um elogio nostálgico do conflito do XIX e de sua versão ideológica posterior ${ }^{20}$, que exalta e vitimiza aquelas que "assumiram a chefia de seus lares e passaram a ser a única coisa que ficou de poder e autoridade no país. Ficaram nessas posições por serem viúvas, com filhos para criar e com a enorme responsabilidade de ressuscitar uma nação moral e materialmente devastada" (idem).

\footnotetext{
17 Veja-se: <http://www.lanacion.com.ar/1122926-el-escandalo-paraguayo>.

18 Cf. Aguero (2012)

19 Para o caso brasileiro e, nele, a relação entre imagens femininas, nacionalismo e a unificação nacional via imaginário de gênero, veja-se Carvalho (1992).

20 Sobre as críticas à historiografia paraguaia nacionalista e ao papel nela reservado às mulheres, veja-se Rodriguez (2010), Ortolan (2010) e Silva (2010).
} 


\section{SZWAKO, J. O 'mau desempenho' de Lugo: gênero, religião e contramovimento...}

Reação dura e imediata ao 'escândalo' de Lugo veio da oposição partidária. A então presidente da Associação Nacional Republicana - Partido Colorado, senadora Lilian Samaniego, pediu formalmente que o Ministério Público investigasse a paternidade presidencial como um caso de violência sexual. Isso se deu visto que a primeira mulher a ter filho reconhecido por Lugo era menor de idade à época de sua gravidez. A colorada alegou que fazia tal pedido na 'condição de mulher e senadora' e como 'defensora dos direitos das mulheres' ${ }^{\prime 2}$. Samaniego só não foi mais dura que o esboço de reação de um colega colorado, o senador Juan Ziett, que tentou abrir um julgamento político contra Fernando Lugo por que este seria 'ninfomaníaco': "Ziett ponderou que o ex-bispo não poderá seguir em seu cargo se ficar comprovado que padece algum tipo de 'doença vinculante ao sexo'”22. Depois de ter sido criticado, e tendo percebido que não contaria votos suficientes para a consecução do impeachment, o político colorado desistiu de tentá-lo. Embora os dois ataques não tenham prosperado em nível institucional, eles conseguiram minar a figura presidencial ou parte significativa dela. Além da vontade de poder, é comum a ambos a transposição automática de termos e feitos da vida privada para a vida pública. Mais evidente no último caso, segundo o qual uma suposta patologia sexual macularia capacidades morais, esta transposição e os 'escândalos' à sua raiz macularam a credibilidade do ex-presidente utilizando-se das práticas íntimas deste 23 . "O que podemos dizer", afirmou Samaniego à imprensa, "é que Fernando Lugo mentiu durante toda sua campanha, mentiu a essa cidadania paraguaia que confiou nele e hoje perdeu totalmente sua integridade" 24 .

Eventualmente, alguns parlamentares então ao lado do presidente saíram em sua defesa dizendo que as críticas do coloradismo misturavam indevidamente vidas íntima e pública. Nesse cenário delicado, as feministas paraguaias encaravam uma situação dilemática próxima à da esquerda pró-Lugo: como criticá-lo sem fazer o 'jogo da direita'? ${ }^{25}$ Ao contrário do que argumentaram alguns, há tempos os feminismos mostram que esferas doméstica e política são coextensivas e reciprocamente constituintes . mesmo que se desconheça, ou se queira desconhecer, que o contrato sexual é a parte negada e estruturante do contrato social (PATEMAN, 1993). Longe de ser uma questão de foro íntimo, a falta de responsabilidade paterna exemplifica bem a dependência entre público e privado, pois ao homem que vive preponderantemente ocupado com o trabalho produtivo e despreocupado com os efeitos potencialmente reprodutivos de suas relações afetivo-sexuais corresponde uma mulher 'dedicada' (leiase, responsabilizada pela atenção) à casa, ao cuidado de infantes ou maiores, à prevenção da gravidez e à sua eventual continuidade. A despreocupação daquele depende da atenção despendida por esta.

\footnotetext{
${ }^{21}$ Veja-se:<http://www.ultimahora.com/notas/215295-El-estupro-enfrenta-a-la-titular-de--ANR-con-el-presidente-Lugo>.

22 Veja-se:

<http://www.que.es/ultimas-noticias/espana/200905140022-califican-disparate-acusacion-ninfomano-lugo.html?anker_1>.

23 Essa forma de tradução direta dos conteúdos da vida íntima para foro político-público não assume somente sentido difamatório. Também pode ocorrer que sinais positivos de pessoas privadas sejam estrategicamente utilizados e transpostos para 'salvar' figuras políticas, a exemplo do que aconteceu nos julgamentos de torturadores e militares na Argentina. Contra esse tipo de transposição, Beatriz Sarlo sustentou que "não é necessário achar que todos os torturadores foram pais cruéis. (...) As virtudes privadas [contudo] não atenuam seus crimes" (SARLo, 2005, p.164).

24 Veja-se: <http://www.ultimahora.com/notas/215295-El-estupro-enfrenta-a-la-titular-de--ANR-con-el-presidente-Lugo>.

25 Substituindo-se os termos-chave desse dilema, essa foi mutatis mutantis a mesma situação encarada pelas feministas estadunidenses frente ao 'escândalo' envolvendo o presidente Clinton. O dilema delas era: como criticar Clinton sem fazer o jogo dos Republicanos? Para a reação das feministas da NOW, veja-se 'Women leaders take action to stop impeachment'. Disponível em: <http://www.now.org/press/09-98/09-24b98.html>. Sobre a fraca vinculação entre esferas íntima e pública operante na opinião pública estadunidense, veja-se Bennett (2002) e Lawrence e Bennett (2001).
} 
OPINIÃO PÚBLICA, Campinas, vol. 20, no 1, abril, 2014, p. $132-155$

Para o feminismo paraguaio, o dilema era explicitar os conteúdos desiguais e hierárquicos dessa interdependência sem, contudo, inspirar a oposição partidária. Em seu comunicado à opinião pública paraguaia, a Coordenação de Mulheres do Paraguai (CMP), a mais antiga rede feminista do país, deixou expresso seu 'repúdio à atitude irresponsável e machista do presidente', exigindo dele 'políticas sobre direitos sexuais e reprodutivos sem discriminações nem hipocrisias' (CMP, 2009). Essa demanda crítica foi feita em dez pontos, dentre os quais destacam-se: 'paternidade responsável, um assunto de interesse público'; 'o poder de um homem não está acima da lei'; 'a conduta do presidente reflete a persistência da ordem patriarcal'; bem como, 'em um Estado laico não existem discriminações nem privilégios baseados na religião'. A natureza interdependente das esferas pública e privada foi evidenciada no argumento da CMP por meio de um slogan clássico:

“Há décadas, um lema feminista é 'o pessoal é político': [ou seja] o que aparentemente é uma experiência individual e [aparentemente] sem alcance político tem caráter político porque é parte de um sistema geral de dominação masculina e subordinação feminina. A vigência de direitos que rompem com esta dominação é resultado de lutas cidadãs que devem ser conhecidas e reconhecidas por todas e todos"(CMP, 2009).

Esse 'sistema geral' não é senão o chamado patriarcado ou 'ordem patriarcal', da qual a irresponsabilidade de Lugo é, para elas, um reflexo. Neste sentido, o então presidente "é parte de uma cultura de dominação masculina com plena vigência na sociedade paraguaia" (idem). Embora responsabilize o então presidente pelo desreconhecimento tanto de seu filho quanto dos direitos que o protegem, este argumento se descola da pessoa de Fernando Lugo para enfatizar a realidade mais ampla e politizada na qual a irresponsabilidade paterna e o combate a ela ganham sentido. "Como cidadão paraguaio, o presidente não está acima das leis e deve cumprir seus deveres de reconhecimento, cuidado e alimentação daqueles que sejam seus filhos". Nessa mesma toada, a tomada pública de posição de uma militante da CMP permite notar como o argumento feminista ganhou uma ênfase não. personalista e politizadora: "mais além de seus detalhes íntimos, a paternidade de Lugo é um assunto público, não apenas devido a quem é o protagonista, mas pelo conteúdo que rodeia o caso" (SoTo, 2010, p.107).

Ao terem deslocado o foco de crítica, exigindo a responsabilização legal das condutas de Lugo e inserindo-as num quadro patriarcal mais amplo, as feministas contornaram a direita paraguaia ávida por razões para alavancar um impeachment e por conseguir a destituição presidencial. Mais do que isso, a CMP dirigiu-se e opôs-se abertamente aos "partidos políticos e setores dominantes (...) [que] se valem da vitimização das mulheres para seus próprios interesses. (...) Não busquem fazer de nossas demandas 'bucha de canhão' para suas pretensões políticas" (CMP, 2009). Para a rede feminista, falar de patriarcado não significa falar de vítimas femininas ou algozes masculinos: "preocupa-nos que as referências a estes casos [denunciados de paternidade] reforcem outros estereótipos atribuídos às mulheres: pobres vítimas desprotegidas, como seres incompletos que precisam de um homem que as complete" (idem). Foi, então, através de um enquadramento não vitimizante e não personalista, que aquele dilema feminista foi respondido. Em tal enquadramento são as práticas e consequências patriarcais da conduta irresponsável de Lugo (e não a sua pessoa e sua intimidade) que devem ser julgadas, não em termos morais, mas segundo uma gramática de direitos. "Parece-nos importante que o 
SZWAKO, J. O 'mau desempenho' de Lugo: gênero, religião e contramovimento...

desenvolvimento dos fatos demonstre que existem mecanismos e ferramentas para exercer direitos, que devem ser cumpridos inclusive por aqueles que detêm o poder" (idem).

Houve mais questões e posturas ao redor das denúncias de paternidade presidencial ${ }^{26}$, mas esta série de dados permite ver, no mínimo, duas posturas frente aos 'escândalos'. O coloradismo faz uso estratégico deles para potencialmente reabrir, via julgamento político ou processo criminal, suas chances de acesso ao Executivo. As feministas, por sua vez, contornaram a vontade de poder colorada, enquadrando o caso em uma 'ordem patriarcal' mais ampla e, ao mesmo tempo, demandando a tradução das injustiças e hierarquias afetivo-sexuais para uma gramática de direitos. Combater a paternidade irresponsável, nestes termos, não é só responsabilizar Lugo, mas detectar e transformar as bases institucionais do sexismo patriarcal; dentre as quais está a "hierarquia católica [que] tem protegido a dupla moral reinante, usando o púlpito e seu poder para (...) negar os direitos sexuais e reprodutivos das pessoas, protegendo, por sua vez, seus próprios membros" (CMP, 2009).

$\mathrm{O}$ argumento feminista passou ao largo do interesse colorado, mas não foi exitoso em interpelar de modo robusto a esquerda partidária e frações amplas da opinião pública paraguaia (ORTIZ, 2009). Ao anexar discursivamente as pessoas íntima e pública de Lugo, questionando sua 'integridade' ou patologizando-o, o coloradismo endossava quem não suportava mais tanta 'sem-vergonhice' no país. Foi este o tom das reações provocadas por um programa de televisão humorístico no qual foram interpretadas as mulheres que alegavam ter tido filhos com o então presidente. Aí elogios rasgados ao humor das personagens digladiam com ataques dirigidos aos atores 'degenerados' que, travestidos, interpretavam as acusadoras. No debate público eram tematizadas responsabilidades presidencial e paterna, enquanto uma intimidade pública era servida no jantar.

Embora tenha saído de cena por alguns meses, a vida sexual presidencial voltou em 2012 à mídia nacional e internacional. Lugo reconhecera outra criança poucas semanas antes de sua destituição. Estava extraoficialmente declarado aberto o julgamento moral do ainda presidente: "O que Lugo tem é uma desordem sexual”, sentenciou um representante eclesiástico27. Em sua opinião, a paternidade não era motivo para depor Lugo, pois ela 'não é questão de Estado', embora revele 'um homem hipócrita e fraco no qual não se pode confiar'. Velho conhecido do feminismo, esse discurso quer acreditar e fazer acreditar que a maioridade moral, bem como as correlatas capacidades de estabelecer contratos e perseguir justiça seriam maculadas por uma 'desordem sexual' (PATEMAN, 1980). Afinado àquela acusação colorada, ele aciona estratégias clássicas de patologização e produção do abjeto: "[o monsenhor] sublinhou que, como ninguém nunca controlou o problema do então bispo de San Pedro, este seguiu no seu erro e nunca pode solucionar sua 'desordem'”. Este foi o prelúdio do massacre de Curuguaty e do réquiem presidencial também.

\section{Movimento e contramovimento em disputa pela 'família'}

Pouco tempo após a legalização do matrimônio entre pessoas do mesmo sexo, ocorrida em junho de 2010, na Argentina, um conjunto de organizações paraguaias conformou o movimento

\footnotetext{
${ }^{26}$ Enquanto Gloria Rubin, feminista histórica e então Ministra da Secretaria da Mulher, veio a público manifestar o suporte legal e técnico de seu órgão estatal a duas denúncias posteriores ao primeiro caso de reconhecimento paterno, aquele defensor nacionalista da 'dignidade das mulheres' afirmou que Rubin e outras “mulheres que Ihe acompanham [a Lugo] em sua administração (...) deveriam agachar a cabeça e assumir a desonra de ter humilhado e traído seu gênero" (AGUERO, 2012).

${ }^{27}$ Veja-se: <http://www.ultimahora.com/segun-monsenor-ortiz-lo-lugo-es-un-desorden-sexual-n534440.html>.
} 


\section{OPINIÃO PÚBLICA, Campinas, vol. 20, no 1, abril, 2014, p. 132-155}

'Queremos papá y mamá', cujo marco inicial foi o festival 'a favor da família' realizado em outubro daquele mesmo ano. À frente dessa iniciativa estavam os integrantes da Federação de Pais de Alunos de Instituições Educativas do Paraguai (FEDEPAR) e da Federação Pró-vida e Família do Paraguai (FEDAVIFA). Esse movimento, porém, compreende uma ampla heterogeneidade interna que abarca desde grupos de médicos, de advogados e de mulheres a frações dos partidos liberal e colorado, bem como organizações de denominações religiosas tanto evangélicas como católicas, ligadas ou não ao catolicismo institucionalizado.

A máxima do então vice-presidente Franco sintetiza de modo mui adequado aquilo que parecia estar em risco para ele e seu público: 'jamais perderemos a família e Deus'. Além deste aliado, o movimento 'pela família' contava também com uma parte colorada da Câmara municipal de Assunção que apoiou a realização daquele festival. Debaixo do sol ensolarado do sábado de 2 de outubro, os fiéis convencidos do risco que corria a família paraguaia compareceram em peso e deixaram manifesto seu heterossexismo: 'papá y mamá' e ponto. O alto investimento do movimento, expresso em uma infraestrutura técnica de ponta, só foi ultrapassado pelo tom dos discursos proferidos no palanque e replicados em cartazes, bandeiras e camisetas: 'não mudem a lei de Deus', 'castidade até o casamento' e, mesmo, 'não à camisinha' dão ideia do naipe das reivindicações.

Aos olhos de um leigo em Paraguai, esses apelos fazem parecer que o casamento entre pessoas do mesmo sexo estaria na iminência de sua aprovação no país; como se a 'família' imaginada e defendida por aqueles em protesto estivesse realmente em risco. À diferença do que parece, no entanto, a ampliação do direito ao matrimônio estava, e permanece, longe do Legislativo paraguaio. Mais ainda, no movimento paraguaio de lésbicas, gays, bissexuais, transexuais e intersex (doravante, movimento LGBTI), a luta pelo matrimônio não é ponto pacífico de discussão e sequer uma prioridade para parte de suas organizações (POSA, 2010).

Menos do que reagir contra um perigo real e iminente, o protesto de 'Queremos papá y mamá' encerrava uma reação desproporcional característica dos fenômenos de 'pânico moral'28. Por meio de seu protesto, o discurso conservador criava e combatia seus inimigos-alvo, que mais recentemente são as organizações e militantes do movimento LGBTI, mas que ao longo da década de 1990 foram basicamente as feministas. Estes novos inimigos, se ampliado o direito ao casamento, colocariam em jogo uma peça fundamental da ordem estabelecida, a 'família' - essa 'doadora moral de status' (VALCÁRCEL, 2011, p.226). Como sublinharam as militantes do movimento lésbico, "a geração deste pânico moral tem como eixos o [Marco Reitor Pedagógico para a Educação Integral da Sexualidade] MRPEIS, a 'ameaça' significada pelo matrimônio igualitário argentino e, em menor medida, o projeto de lei de saúde sexual e reprodutiva, bem como a despenalização do aborto" (MORAGAS E POSA, 2010, p.218).

Assim, a conquista do movimento LGBTI argentino serviu como justificativa para o discurso familista delinear-se enquanto tal, mobilizando suas bases e a opinião pública. Mas seu objeto de preocupação era, com efeito, o projeto de saúde sexual e reprodutiva e o marco reitor. Vejamos

${ }^{28}$ Cf. "O conceito de pânico moral permite lidar com processos sociais marcados pelo temor e pela pressão por mudança social. (...). [0] pânico é moral porque o que se teme é uma suposta ameaça à ordem social ou a uma concepção idealizada de parte dela, ou seja, instituições históricas e variáveis, mas que detêm um status valorizado como a família ou o casamento" (Mıskolcı, 2007, p.112) 
SZWAKO, J. O 'mau desempenho' de Lugo: gênero, religião e contramovimento...

primeiramente a reação àquele projeto para em seguida ver as disputas travadas pelo marco. Duas vezes apresentada no Senado paraguaio por um aliado do feminismo, o senador Carlos Filizzola, a 'Lei de saúde sexual, reprodutiva e materno perinatal' foi reprovada tanto em 2007 como no ano seguinte. Esta segunda tentativa, no entanto, rendeu a abertura de um processo de consulta a organizações civis. Aberta a oportunidade, um membro fundador de FEDAVIFA redigiu "Aborto, morte e gênero por detrás das palavras. Um exemplo prático de como introduzir leis para descriminalizar o aborto e inserir a homossexualidade como direito" (CALCATERRA, 2008).

'Detrás' do projeto de lei rechaçado, o pensador 'pró-vida' vê ocultações. "A despenalização do aborto é um aspecto oculto (...) do 'Projeto F' [de Filizzola]. Este objetivo [de ocultar] está influenciado por aspectos como a 'perspectiva de gênero', a 'livre opção sexual' e a mentalidade anticonceptiva" (CAlCaterRa, 2008, p.10). Isoladas ou conexas, essas categorias correspondem aos inimigos, novos e velhos, agora encarnados no anteprojeto, "[que] menciona o aborto não como um delito que deve ser combatido, mas como problema que deve ser solucionado [segundo o 'Projeto F'] com educação e anticonceptivos e possivelmente com mais abortos, porém legais" (idem, p.11) (Grifo no original). Na lista de entes 'abortistas' são elencadas ONGs feministas, agências do sistema das Nações Unidas e redes internacionais. Segundo o ultracatólico, elas tanto 'exageram' (idem, p.15) os índices de mortalidade materna, quanto Ihes usam como 'pretexto para salvar a saúde ou a vida da mãe' (idem, p.16).

Uma lei informada pelo discurso feminista, de alcance nacional e, sobretudo, com implicações para a regulação dos usos do corpo feminino, gera pânico, confusão e paranoia. Ao ter como objetivo 'reduzir a violência e o abuso sexual de mulheres, crianças e minorias sexuais', o 'Projeto F' daria, supostamente, 'abertura para o matrimônio homossexual' (CALCATERRA, 2008, p.20). Essa pretensa conexão e sua falta de clareza não surpreendem, pois a defesa da natalidade a qualquer preço é já uma defesa "[das] estruturas familiares que fazem do nosso Paraguai um lugar onde a família é o centro e eixo da nossa nação" (idem, p.14). E aqui, no cruzamento do 'pró-vida' com o 'pela família', é mais uma vez a nostalgia bélico-nacionalista que molda a disposição dos atores. "Como nação, devemos dizer não para estas posições e relembrar a fortaleza da família paraguaia que soube sobreviver aos impactos das guerras e da invasão de ideias estrangeiras" (idem, grifo do autor). 'Em avaliação' ad infinitum, o anteprojeto não foi mais posto para votação no Congresso.

O 'Marco Reitor Pedagógico para a Educação Integral da Sexualidade' (PARAGUAY, 2010) não ficou no mesmo vácuo institucional do 'Projeto F'. Depois de ter passado por dois anos de consulta civil, incluindo estudantes, docentes, gestores e líderes religiosos, o Ministério da Educação decidiu 'socializar' em setembro de 2010 o texto do marco reitor. Orientado por noções como 'direitos humanos, perspectiva de gênero e interculturalidade', o documento abriu uma arena de batalha estendida entre a segunda metade de 2010 e por todo o ano seguinte. De um lado, militantes do feminismo e do movimento LGBTI, e figuras como as Ministras da Mulher e da Saúde, vinham a público declarar seu apoio ao documento. De outro, as primeiras reações exageravam um pouco, prevendo que o Ministério da Educação iria impor, 'desde a pré-escola, conceitos com relação a temas sensíveis como a anticoncepção, a homossexualidade ou a diversidade sexual' ${ }^{29}$. Neste mesmo sentido, figuras das

\footnotetext{
${ }^{29}$ Veja-se: <http://blogs.ultimahora.com/post/3451/87/gustavo-olmedo.html>.
} 


\section{OPINIÃO PÚBLICA, Campinas, vol. 20, no 1, abril, 2014, p. 132-155}

organizações 'pró-vida' presentes no ensolarado palanque de 'papá y mamá' afirmaram que a proposta ministerial 'corromperia' as escolas e as crianças.

A preocupação com os infantes tinha pouca base. Ainda que mencionasse uma só vez o termo 'diversidade sexual', o texto apresentava como eixos distintos a 'sexualidade' e a 'diversidade', sem falar em bi ou homossexualidade; sem falar, portanto, de sexualidades no plural. Seja como for, o marco reitor contou com a defesa de organizações de direitos humanos, de direitos da criança e do adolescente e ainda com associações profissionais de medicina e psicologia. Entre estas últimas, o argumento a favor do marco desmentia a suposta defesa da ampliação do casamento, ao mesmo tempo em que despatologizava publicamente a homossexualidade.

Para o contramovimento familista, no entanto, o cerne da discórdia estava no uso da 'perspectiva de gênero' - a mesma que 'oculta' a descriminalização do aborto no 'Projeto F'. Por toda a América Latina, os fundamentalismos religiosos, pelo menos desde a Conferência Mundial da Mulher, vêm travando batalhas morais contra a noção de gênero (FRANCO, 1996). O Paraguai não é exceção. No texto do marco, essa noção designa "a base da construção social do feminino e do masculino (...) [e] permite compreender que os padrões de organização baseados nas diferenças sexuais (biológicas) são construções sociais" (PARAGUAY, 2010, p.20). No vocabulário dos adversários religiosos, porém, isso não passa de algo 'ideológico', é a “'ideologia de gênero', que pretende nada menos que a 'liberação total do ser humano', desmontando ('desconstruindo') o que a humanidade construiu com tanto esforço e milênios sobre suas relações familiares, a reprodução, a educação, a religião" - tal como opinou em nota um jesuíta paraguaio ${ }^{30}$. A postura desse jesuíta seria apenas mais uma em jogo não fosse sua posição estratégica no Conselho Nacional de Educação e Cultura $^{31}$. Sob pressão deste órgão, o Ministro da Educação deixou sem efeito tanto a socialização quanto a aplicação do marco. Enquanto alguns viam nesta decisão uma 'covardia', outros a 'festejaram'32. Um ano após seu primeiro protesto, a edição de 2011 do festival de 'Queremos mamá y papá' teve como lema 'Sim à vida, não ao marco reitor que atenta contra a infância'.

As disputas travadas tanto pelo marco reitor quanto por aquele projeto de lei permitem sugerir nuances à compreensão do par movimento/contramovimento. As partes em concorrência são, centralmente mas não exclusivamente, organizações antiabortistas e familistas e, de outro lado, as organizações LGBTI e do feminismo paraguaio. À primeira vista, poderíamos dizer que os objetos de preocupação compartilhados e disputados entre essas partes são o marco reitor, o projeto de lei de saúde sexual e reprodutiva, bem como modelos de família. Relativamente aos dois primeiros, é certo que tanto os usos do corpo feminino quanto o imaginário e práticas escolares são objetos tematizados, com sinais e sentidos opostos, por aquelas partes.

No caso da 'família', no entanto, as coisas não são tão simples. Se a variedade sexuada de sujeitos e contratos matrimoniais legalmente reconhecidos preocupava muito ao coro familista anti.

\footnotetext{
30 Veja-se: <http://www.abc.com.py/edicion-impresa/opinion/sexo-genero-y-educacion-193688.html>.

31 Para muito além do caso paraguaio, a ocupação de posições político-administrativas é, com efeito, tendência preponderante na estratégia dos familismos conservadores de toda a América Latina. Vejam-se os artigos reunidos em Corrêa e Parker (2011) e, para o caso peruano, Mujica (2011).

32 Veja-se: <http://www.lanacion.com.py/articulo/40669-comunidad-educativa-festeja-que-se-suspenda-aplicacion-del-marco rector.html>.
} 
SZWAKO, J. O 'mau desempenho' de Lugo: gênero, religião e contramovimento...

homossexual paraguaio ${ }^{33}$, apenas uma parte das organizações LGBTI investia nessa agenda, mas sem pistas de sucesso, pois um projeto de lei com tal conteúdo nunca foi sequer apresentado no parlamento paraguaio. Quer dizer, a 'família' não constitui aí um objeto comum e realmente em disputa (legislativa, neste caso). Ela é, antes, produto dos pânicos morais do familismo conservador, que cria um objeto próprio e relacionalmente imputado, mas não compartilhado. Esse foi o caso da 'família paraguaia' que, depois de ter 'sobrevivido a guerras e invasões', precisaria sobreviver a um projeto de lei de saúde sexual e reprodutiva.

Essa distinção entre objeto real em disputa e os recursos discursivos que produzem objetos 'em risco' ou 'perigo' não parece, contudo, estar acessível a uma concepção convencional do par movimento/contramovimento. Ao dar ênfase analítica aos objetos compartilhados de preocupação, essa concepção não quer limitar o uso do termo 'contramovimento' a formas 'essencialmente reacionárias de oposição' (Meyer E StAgGenborg, 1996, p.1632). Embora ganhe em fôlego analítico, ela perde a inspiração normativa de definições que enfatizam no contramovimento a mobilização "para bloquear uma mudança sócio-institucional ou para voltar a um status quo prévio" (MOTTL, 1980, p.624). É neste sentido que 'Queremos papá y mamá' se opõe à mudança potencialmente contida no marco reitor e, para isso, cria discursiva e exitosamente outro objeto (as 'crianças') a ser protegido de uma suposta e supostamente ameaçadora 'ideologia de gênero'.

A despeito dessa lacuna normativa em sua definição, Meyer e Staggenborg (op. cit., p. 1635) apontam para dois fatores operantes na gênese contramovimentista: 'aliados políticos' e o 'sucesso' do movimento inicial em relação ao qual se contrapõe. Exemplos de aliados do familismo são o então vice. presidente e a administração assuncena. Mais ainda: a posição-chave de um aliado religioso foi decisiva para selar o destino institucional do marco reitor. No outro lado da pugna, as organizações feministas e do movimento LGBTI contavam igualmente com o apoio de figuras ministeriais e parlamentares em defesa dos objetos estatais em disputa. À raiz dessas tomadas de oposição está a série anterior e acumulada de interações entre atores estatais e sociais através das quais aliados da polity são convencidos e conquistados. Mas não só eles, pois os objetos em disputa nesta dinâmica movimento/ contramovimento trazem também a marca das interações anteriormente travadas com organizações do feminismo. Guiados pela 'perspectiva de gênero', o marco e o projeto estão inseridos na tendência de generificação do tecido estatal paraguaio e notadamente de seu Executivo (SzWAKo, 2012b), produzida a partir de diversas interações sócio-estatais. É, então, contra o sucesso relativo da generificação estatal que se opõe o conservadorismo 'pró-vida' e pela 'família'. Apesar dos esforços conservadores, essa tendência parece não ter diminuído após a eleição presidencial de 2008; aliás, pelo contrário, segundo um órgão da hierarquia católica do país, o 'Governo de Lugo promove a ideologia de gênero'34 - exageros e enquadramento à parte, essa sentença muito provavelmente está correta, mas por razões institucionais e raízes sócio-estatais que ainda cumprem conhecer.

\section{'Mau desempenho' moral: da vida privada à morte presidencial e duas implicações}

As reações à queda de Lugo, aos 'escandalosos' casos de paternidade presidencial, assim como as disputas pela 'família paraguaia', permitem inferir três tipos de observação. Em primeiro lugar, os

\footnotetext{
33 Sobre familismo conservador no Brasil, veja-se Mello (2006).

${ }^{34}$ Veja-se El Observador Semanal (2011, p.3).
} 


\section{OPINIÃO PÚBLICA, Campinas, vol. 20, no 1, abril, 2014, p. 132-155}

dados dão acesso aos valores e padrões de gênero vigentes no Paraguai, e cujos usos e enquadramento, em boa medida, serviram de fonte de legitimação da última destituição presidencial. Em segundo lugar, eles permitem discernir atores politicamente organizados em função de sua filiação religiosa e notadamente negligenciados no quadro teórico mais amplo da Ciência Política. Permitem, por fim, visualizar possibilidades e caminhos heurísticos abertos pelo par movimento/contramovimento. Para finalizar, vamos àquele primeiro ponto.

A intersecção entre 'escândalos' bem aproveitados pela mídia e pela oposição partidária (apenas publicamente mais sedenta que a vice-presidência pela liderança do Executivo) e um não comprovado 'mau desempenho' das funções presidenciais (pretensamente expresso em Curuguaty) resultou em um julgamento político fatal. 'Hipócrita', 'sem vergonha' e 'bispo de araque' são só três dos adjetivos reproduzíveis atribuídos ao presidente deposto. Após a queda, a tendência a explorar supostos vícios íntimos de Lugo, transpondo-os para sua figura pública, só fez aumentar. "A batina vestia mais que um pastor, escondia um homem frio, ambicioso, ingrato e profundamente amoral" (AVALOS, 2012). Piadas, chistes e detalhes sobram: 'vida de esbanjo', 'viagens exóticas', uma ultrajante 'banheira presidencial' nacionalmente conhecida, 'festas privadas' e até 'assistentes' descrevem o ambiente em que Lugo foi enquadrado35. Estes juízos anteciparam o julgamento político. Assim, seu 'mau desempenho' moral, isto é, essa figura forjada com base na anexação das pessoas íntima e pública de Lugo, contornou discursivamente a lógica do campo institucional - onde o abismo entre Executivo e Legislativo ecoou efetivamente no réquiem presidencial.

Valores de gênero e religiosos em conjunto estão na base dessa transposição moralizante. Para isso contribui claramente o fato de o ex-presidente ser uma figura eclesiástica quando de suas incursões sexuais. Essa conjunção observada nos 'escândalos' de paternidade presidencial encerra também traço em comum com o elogio do resultado do julgamento contra Lugo e com a defesa conservadora da 'família': a nostalgia do nacionalismo bélico. Nos três casos, é a imaginação de um país de passado glorioso, com líderes fortes e mulheres guerreiras, contra os vizinhos invasores, que informa a fala dos atores. O compartilhamento dessa matriz nacionalista, contudo, não implica em uma só e mesma base social desses discursos e sequer numa coerência (ideológica, de classe ou outra) entre eles. O que se vê são atores orientados por uma mesma matriz, que Ihes fornece o enquadramento através do qual eles traduzem suas reivindicações religiosas e seus pânicos de gênero.

Na medida em que molda a ação e a imaginação dos críticos de Lugo, a matriz nacionalista mantém relação oblíqua com seu impeachment. Em plano internacional, opera a lógica 'Paraguai versus inimigos', evidenciada no tom de 'Paraguay es soberano' e expressa, por exemplo, na oposição familista à 'perspectiva de gênero' que, além de 'corromper' infantes, poderia macular a 'soberania cultural do país'36. Quase a mesma lógica se reproduz em plano interno, pois, para o discurso nacionalista, quem não está ao seu lado (isto é, não compartilha dessa versão belicosa de país) estaria contra o 'Paraguai'. Em tais termos, quem não adere a posturas nacionalistas são os outros do nacionalismo, são inimigos internos, os 'antiparaguaios'37. Daí, então, as supostas difamações e a perseguição anticomunistas

\footnotetext{
${ }^{35}$ Veja-se: <http://m.abc.com.py/edicion-impresa/editorial/el-turismo-de-lugo-le-costo-caro-al-paraguay-431072.html>.

${ }^{36}$ Veja-se: <http://blogs.ultimahora.com/post/3451/87/gustavo-olmedo.html>.

37 'Antiparaguaios' é termo das análises de Rodriguez-Zucolillo (2000) e de Rodriguez-Alcalá (2005) a respeito, respectivamente, do nacionalismo linguístico e da ideologia autoritária no Paraguai.
} 
SZWAKO, J. O 'mau desempenho' de Lugo: gênero, religião e contramovimento...

desatadas contra aqueles que 'resistem ao golpe' ou 'apoiam a Lugo', agora transformados em 'párias' no dicionário belicoso. O título do festival promovido por uma organização lésbica ironiza seus adversários civis: "Esquerdistas, bichas, comunistas e filhos da puta...: mensagens da crise política nos meios de comunicação". Ninguém, no entanto, resumiu tão bem as disputas de gênero, e a infraestrutura sócio-civil na base delas, do modo como o fez um Senador de ultradireita, que chamou as bases de Lugo de 'marxistas leninistas e promotores do casamento gay'. "Nós que somos éticos", ele disse, "não estamos de acordo com o matrimônio gay. O homem e a mulher são a célula fundamental da família"38 - para os atores civis e políticos em pânico, Lugo ou o seu governo teria, relativamente às questões de gênero e de generificação estatal, tido péssimo desempenho moral.

Este conjunto de reações seja ao impeachment de Lugo ou àquelas iniciativas institucionais permite extrair uma primeira implicação: a necessidade de compreender o fenômeno religioso como parte legítima da disputa política (VAGGIONE, 2011) bem como das análises politológicas. 'Queremos papá y mamá' e a posição estratégica daquele jesuíta são apenas dois exemplos do volume de energia e recursos despendidos por fiéis e organizações religiosas para se impor sobre a institucionalidade política. A postura da hierarquia católica frente à queda de Lugo vai neste mesmo sentido: depois de ter pedido a renúncia do ainda presidente, ela se apressou em reconhecer o governo franquista.

Do ponto de vista do debate normativo, esse ímpeto religioso para incidir e mesmo decidir institucionalmente tem sido alvo de acalorado debate ${ }^{39}$. A meu ver, porém, tomadas de posição como as de 'Queremos papá y mamá' exigem uma análise positiva (empírica) do religioso, dos atores e valores religiosos. Para tal análise, a Sociologia Política e a Ciência Política podem contar com ajuda antropológica e, em especial, com sua crítica a uma tradução fatalista do diagnóstico weberiano da secularização, que parece ter indevidamente afastado o religioso das análises politológicas. Não se trata,

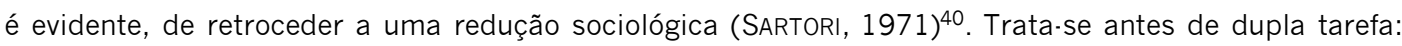
reconhecer o desvio das clivagens e morais religiosas em relação a supostos rumos secularizantes (BURITY, 2008) e, daí, inquirir os laços e as estratégias sócio-estatais através das quais conflitos, atores e valores estruturados por clivagem religiosa têm ganhado vazão e tradução político-institucional.

Bem observados, esses dados apontam para uma Ciência Política da religião, preocupada com formas associativas religiosamente orientadas, com suas alianças e efeitos político-públicos, e cujo objeto pode ser analisado em dois níveis (separados e articulados): o nível relativo à hierarquia institucional (eclesiástica ou outra) e, de outro lado, o nível das associações civis estruturadas por filiação religiosa. Em ambos os níveis, trata-se de entender tanto o arco das estratégias e alianças partidárias e de sua manutenção, como o continuum das relações (autônomas e/ou dependentes) travadas entre o oficialato religioso, as organizações leigas ou não e a base mais ampla de fiéis. Qual o peso da variável religiosa na disposição dos atores e em diversos cenários institucionais? ${ }^{41}$ Por exemplo,

\footnotetext{
38 Veja-se: <http://eleccionesparaguay2013.com/marxistas-leninistas-y-promotores-del-matrimonio-gay>.

${ }^{39}$ Veja-se, inter alia, Butler et al (2011) e também Connolly (1999).

40 Postura observável, indiretamente, na análise que resume a política-institucional a um 'subsistema social', entre outros subsistemas com os quais a Igreja Católica, neste caso específico, italiana trava relações. Cf. "O papel desempenhado pela Igreja Católica Italiana em controvérsias bioéticas não pode ser reduzido apenas a uma interferência na esfera política: ela [a Igreja] lutou (...) para se comunicar com vários subsistemas sociais (direito, ciência, amor, economia, política)" (PACE, 2012, p.43-44); ainda que tal postura esteja em sintonia com uma análise antropológica das "modalidades de presença religiosa no espaço público [lato sensu]" (Oro et al, 2012, p.8) (Grifo no original).

${ }^{41}$ Muito embora uma análise politológica dos atores e fatores religiosos não deva recair em qualquer tipo de redução societal, é inevitável seu diálogo com a antropologia da religião; dentre outras razões propriamente teóricas e de apropriação do diagnóstico
} 


\section{OPINIÃO PÚBLICA, Campinas, vol. 20, no 1, abril, 2014, p. 132-155}

qual o peso relativo da religião seja em autoridades executivas que operam as políticas seja na disposição eleitoral de fiéis? Se, como e em que medida as associações civis religiosas negociam e sintetizam preferências difusas dos fiéis ou de suas respectivas hierarquias? Isto é, elas exercem representação? Na esteira de problemas postos por autores como J. Burity, essas e outras questões podem, a meu ver, aproximar a Ciência Política das Ciências Sociais da religião.

Outra implicação do caso Lugo é a fecundidade analítica dos pares movimento/contramovimento e mobilização/contramobilização. Ao se deslocar de um eixo de análise centrado na interação entre atores estatais e não-estatais, foram vislumbrados embates sócio-civis que complexificam a observação do cenário no qual são tradicionalmente analisados os atores sociais. Em paralelo e em conjunto, o caso das reações à destituição presidencial e o caso do familismo conservador trazem dois traços comuns: o primeiro e mais evidente é o anticomunismo como forma de difamação acionada; o segundo traço, e mais interessante, é como uma das partes em disputa aciona estratégias para confundir frações mais amplas do público. Ao se apropriar do 'micrófono abierto', a fração 'soberanista' insere um elemento de confusão entre si e os 'resistentes', desfazendo estratégica e momentaneamente a diferença entre ambos e dificultando, portanto, a localização das várias enunciações em jogo. O mesmo ocorre com a estratégia exagerada e desproporcional do familismo paraguaio, que, ao criar objetos 'em perigo', nutre pânicos morais e embaralha, a seu favor, a compreensão daquilo que supostamente entra em questão - a 'família' ou as 'crianças', por exemplo. Se o ímpeto para fundir e confundir as oposições em jogo é ou não uma propriedade distintiva das dinâmicas de movimento/contramovimento, tal como acreditamos ${ }^{42}$, é questão que fica sugerida a outras análises triangulares da ação coletiva.

\section{Referências Bibliográficas}

ABC COLOR. El mal desempeño de Lugo hartó a los paraguayos, [Online]. ABC Color, 24 jun. 2012. Disponível em <http://www.abc.com.py/edicion-impresa/editorial/el-mal-desempeno-de-lugo.....harto-a.los-paraguayos418134.html>. Acesso em: 25 jun.2012.

ABERS, R. et al. "A participação na era Lula: repertórios de interação em um Estado heterogêneo". $35^{\circ}$ Encontro Anual da Anpocs, Caxambu/MG, 24 a 28 out. 2011.

Aguero, L. Fernando Lugo humilló a la mujer paraguaya, [Online]. 02 fev. 2012. Disponível em: <http://www.diariosigloxxi.com/texto-diario/mostrar/80321/fernando-lugo-humillo-a-la-mujer-paraguaya>. Acesso em: 25 jun.2012.

AlmeIdA, R. Religião em Transição. In: Horizontes das Ciências Sociais no Brasil: Antropologia. São Paulo: Anpocs, p.367.406, 2012

AQUINo, A. "El 56\% de la población aprueba la destitución de Lugo de la presidencia", [Online]. Última Hora, 15 jul. 2012. Disponível em: <http://www.ultimahora.com/notas/545327-El-56\%20-de-la-poblacion-aprueba-la-destitucion-deLugo-de-la-presidencia>. Acesso em: 23 jul.2012.

Avalos, C. "A guarânia do engano", [Online]. Blogs Veja, 26 jun. 2012. Disponível em: <http://veja.abril.com.br/blog/augusto-nunes/feira-livre/a-guarania-do-engano-por-chiqui-avalos/>. Acesso em: 15 set.2012.

weberiano, porque há uma convergência e uma sobreposição das questões colocadas ao objeto. Por exemplo: "por onde passam os interesses da Igreja Católica no aparelho de Estado (...)? Como ela age na política institucional?" (ALmEIDA, 2010, p.384).

42 Caso pungente desta lógica de fusão de posições e proposições pode ser visto na análise da 'confluência perversa' entre os projetos participativo e neoliberal, pois, embora apontem "para direções opostas e até antagônicas, ambos os projetos requerem uma sociedade civil ativa e propositiva" (DAGNINO, 2004, p.97). 
SZWAKO, J. O 'mau desempenho' de Lugo: gênero, religião e contramovimento...

BAREIRO, L. "El humo puede estar cubriendo cambios". En: Informativo Mulher Digital, Panorama, 2009. Disponível em: <http:www.informativomujer.org.py/?p=607>. Acesso em: 15 set. 2012.

Bennett, S. "Another Lesson about Public Opinion during the Clinton-Lewinsky Scandal". Presidential Studies Quarterly, Washington DC, vol. 32, n 2, p. 276-292, 2002.

BIROLI, F.; MIGUEL, L.F. Teoria política e feminismo: abordagens brasileiras. Vinhedo, SP: Horizonte, 2012.

BURITY, J. "Religião, política e cultura". Tempo Social, São Paulo. vol.20, n², p.83·113, nov. 2008.

ButLer, J. et al. The Power of Religion in the Public Sphere. New York Chichester, West Sussex:

Columbia University Press, 2011

CalCateRRA, D. Aborto, muerte y género tras las palabras. Un ejemplo práctico de como introducir leyes para despenalizar el aborto e insertar la homosexualidad como un derecho. Assunção, mimeo, 2008.

Carvalho, J. M. República-Mulher: Entre Maria e Marianne. In: A Crônica: o gênero, sua fixação e suas transformações no Brasil. Campinas: Unicamp, p.505-527, 1992.

COMISIÓN DE VERDAD y JUSTICIA. Informe Final. Anive haguã oiko. Asunción, 2008.

CONAMURI. CONAMUR/ ante el quiebre democrático de Paraguay, [Online]. Coordenadora Nacional de Mulheres Trabalhadoras Rurais e Indígenas, 27 jun. 2012. Disponível em: <http://www.forumjustica.com.br/conamuri-ante-elquiebre-democratico-de-paraguay>. Acesso em: 25 jul.2012.

Connolly, W. Why / am not a secularist. Minneapolis/Londres: University of Minnesota, 1999.

CorrêA, S. \& PARKer, R. (orgs.) Sexualidade e política na América Latina: histórias, interseções e paradoxos. Rio de Janeiro: ABIA, 2011.

Dagnino, E; Olvera, A.; Panfichi, A. A Disputa pela Construção Democrática na América Latina. São Paulo, Campinas: Paz e Terra, Unicamp, 2006.

Dagnino, E. "Sociedade civil, participação e cidadania: de que estamos falando?" Mato, D. (Org.). Políticas de Ciudadanía y Sociedad Civil en Tiempos de Globalización. Caracas: Faces/Universidad de Venezuela, p. 95-111, 2004.

EStigarRIBIA, F. "Juventud paraguaya, una historia de resistencias." América Latina en movimiento. Juventudes en escena. Quito: ALAI, p.18.20, 2012.

FRANCO, J. The Gender Wars, [Online]. NACLA Report on the Americas, 02 abr. 1996. Disponível em: <http://www.hartford-hwp.com/archives/42a/038.html>. Acesso em: 10 fev.2010.

Goldstone, J. Bridging institutionalized and noninstitutionalized politics. In: GolDSTONE, J. States, parties, and social movements. Cambridge: Cambridge University Press, 2003.

LaWrence, R.; Bennett, W. "Rethinking Media Politics and Public Opinion: Reactions to the Clinton-Lewinsky Scandal". Political Science Quarterly, New York, vol. 116, n. 3, p. 425.446, 2001.

MARTIns, I. "Democracia paraguaia", [Online]. Folha de São Paulo, 05 jul. 2012. Disponível em:

<http://www1.folha.uol.com.br/fsp/opiniao/52717.democracia-paraguaia.shtml>. Acesso em: 15 set.2012.

Mello, L. "Familismo (anti)homossexual e regulação da cidadania no Brasil". Revista Estudos Feministas, vol.14, n’2, p.497-508, 2006.

MÉndez Pereira, M. 67\% de la ciudadanía está en contra del 'juicio político', [Online]. Ea.com.py, 21 de junho de 2012. Disponível em: <http://ea.com.py/67-de-la-ciudadania-esta-en-contra-del-juicio-politico/>. Acesso em: 22 jun.2012.

Meyer, D. e Staggenborg, S. "Movements, Countermovements, and the Structure of Political Opportunity". American Journal of Sociology, 101, p.1628-1660, 1996.

MISKOLCI, R. "Pânicos morais e controle social - reflexões sobre o casamento gay". Cadernos Pagu, 28, p.101·128, 2007.

Moragas, M. E Posa, R. "Educación sexual para decidir. Un nuevo marco rector frente a tradicionales formas de "no educación'”. Derechos humanos en Paraguay 2010. Asunción: Codehupy, p. 213-220, 2010.

MOTTL, T. "The Analysis of countermovements". Social Problems, Berkeley, vol. 27, n 5, p.620.635, 1980 


\section{OPINIÃO PÚBLICA, Campinas, vol. 20, no 1, abril, 2014, p. 132-155}

MUJICA, J. Transformaciones políticas de los grupos conservadores en el Perú. In: CORRÊA \& PARKER (orgs.). Sexualidade e política na América Latina: histórias, interseções e paradoxos. Rio de Janeiro: ABIA, p.337-349, 2011.

OkIn, S. Justice, Gender and the Family. New York: Basic Books, 1989.

ORo, A. et al. Introdução. In: A religião no espaço público. Atores e objetos. São Paulo: Terceiro Nome, p.7-14, 2012.

ORTOLAN, F. "Dócil, elegante e caridosa: representações das mulheres paraguaias na imprensa do pós-Guerra do Paraguai (1869-1904)". Curitiba. 289 p. Tese de Doutorado em História, Universidade Federal do Paraná, 2010.

ORTIZ, A. La paternidad de Lugo: una historia de espermas, política y cultura, [Online]. Ea.com.py, 29 abr. 2009. Disponível em: <http://ea.com.py/la-paternidad-de-lugo-una-historia-de-espermas-politica-y-cultura/print/>. Acesso em: 16 set. 2012

PACE, E. A Igreja Católica na Itália como ator ético no espaço público europeu diante da bioética. In: A Religião no espaço público. Atores e objetos. São Paulo: Terceiro Nome, p.29.44, 2012.

Pateman, C. 'The Disorder of Women': Women, Love, and the Sense of Justice. Ethics, vol. 91, n’ 1, p. 20-34, 1980.

Pateman, C. O Contrato sexual. Rio de Janeiro: Paz e Terra, 1993.

PosA, R. "A paso de tortuga y con obstáculos. Situación de derechos humanos de lesbianas, gays, bisexuales, personas trans e interesex". Derechos humanos en Paraguay 2010. Assunção: Codehupy, p. 321·331, 2010.

Rodriguez-Alcalá, G. Ideologia Autoritária. Coleção América do Sul. Trad. Luiz Moreira e Marcela Quinteros. Brasília: Funag/IPRI, 2005

Rodriguez-Alcalá, G. (Org.) Residentas, destinadas y traidoras. Testimonio de mujeres de la Triple Alianza. Asunción: Servilibro, 2010

Rodriguez-Zucolitlo, C. "Língua, Nação e Nacionalismo: um estudo sobre o guarani no Paraguai". Campinas, 254 p. Doutorado em Linguística, Unicamp, 2000.

SARLo, B. Tempo presente. Notas sobre a mudança de uma cultura. Rio de Janeiro: José Olympio, 2005.

SARTORI, G. "Da Sociologia da Política à Sociologia Política". LIPSET, S. M. (Org.). Política e Ciências Sociais. Rio de Janeiro: Zahar, p.106-148,1971.

SILvA, A. La noche de las Kygua Vera. La mujer y la reconstrucción de la identidad nacional paraguaya en la posguerra de la Triple Alianza (1867-1904). Assunção: Continental, 2010.

Sото, C. "Lecciones de la paternidad de Lugo". Observatorio Latinoamericano 2. Dossier Paraguay, Buenos Aires, n², p.106-110, maio, 2010.

SzWAKo, J. "El Marzo paraguayo (1999). Pontes de resistência-estabilização e esfera pública no Paraguai pós-ditatorial". $30^{\circ}$ Congresso da Latin American Studies Association, San Francisco, maio 2012a.

"Del otro lado de la vereda: Luta feminista e construção democrática no Paraguai pós-ditatorial". Campinas, 440 p. Doutorado em Ciências Sociais, Unicamp, 2012b. 2010. .; Adelman, M. (orgs). "Dossiê Teoria Política Feminista". Revista de Sociologia e Política, vol.18, n³6, p.9.13,

TARRow, S. Poder em movimento: movimentos sociais e confronto político. Petrópolis: Vozes, 2009.

TILLY, C.; TARROW, S. Contentious politics. Boulder: Paradigm, 2007.

VAlCÁRCEL, A. "Religiones, sectas y ganancias Morales. El atractivo del fundamentalismo y la desconfianza hacia el feminismo". En: LAGARDE, M. e ValCÁRCEL, A. (orgs.). Feminismo, género e igualdad. Pensamiento Iberoamericano 9. Madrid: AECD; Fund. Carolina, p.211-228, 2011.

VAGGIONE, J. M. Sexualidad, religión y política en América Latina. En: CORRÊA \& PARKER (orgs.). Sexualidade e política na América Latina: histórias, interseções e paradoxos. Rio de Janeiro: ABIA, 2011.

Young, I. Justice and the Politics of Difference. Princeton: Princeton University Press, 1990.

YUVAL-DAVIS, N. \& ANTHIAS, F. (orgs.) Women-Nation-State. London: Macmillan, 1989. 


\section{Documentos citados}

CMP. Comunicado da Coordenação de Mulheres do Paraguai, [Online]. CMP, 05 maio 2009. Disponível em: <http://catolicasonline.org.br/noticias/conteudo.asp?cod=1449>. Acesso em: 10 set.2012.

El Observador Semanal. Carta al director. Gobierno de Lugo promueve le ideología de género, [Online]. 17 de novembro de 2011.2 Disponível em: <http://issuu.com/fundacionsanrafael/docs/observadosemanal>. Acesso em: 30 set.2012.

Paraguay. Congreso Nacional.Cámara de Diputados. Libelo acusatorio. Asunción, mimeo, 2012.

\section{Sites consultados}

www.abc.com.py

www.diariosigloxxi.com

www.forumjustica.com.br

www.lanacion.com.py

www.noticiasclic.com/

www.now.org

www.paraguaysoberano.org

www.sinmiedoapensar.net

www.ultimahora.com

www.youtube.com

José Szwako·zeszwako@hotmail.com

Submetido à publicação em outubro de 2012.

Aprovado para publicação em janeiro de 2013. 